more closely into accord with the high standard of the art work.

\section{Estimation of Calcium in Biological Material}

'THE adaptation of the flame-photometer to the ostimation of calcium in biological material has proved difficult because of serious interference from other ions commonly present. Sodium and phosphate ions are specially trouble. some, sodium exhancing and phosphates inhibiting the intensity of the calcium flame. Other ions also interfere in varying degrees of severity. The intrinsic simplicity of flame-photometry, however, has made worth whilo tho developmont of several techniquos for isolating calcium ions free from interfering material. G. E. Trout, of the University of the Witwatersrand, Johannesburg, has recently described an improved technique whereby tho calcium is purified by means of ion-exchange chromatography on fine-mesh resins (South Afric. J. Med. Sci., 27, Nos. 1 and 2; July 1962). It is particularly suitable for the estimation of calcium in tissue ashes. The method has been extensively tested with a synthetic mixture of sodium, magnesium, potassium and calcium salts.

\section{Control of Ticks on Livestock}

IN 1958 an expert panel on tick-borne diseases of livestock was established by the Food and Agriculture Organization, the first meeting of this body being held in November of that year. The recent publication, The Control of Ticks on Livestock, is the first to be provided by the panel (FAO Agricultural Studies No. 54. Preparod by S. F. Barnett. Pp. vii +115. Rome: Food and Agriculture Organization of the United Nations; London: H.M.S.O., 1961. 5s.; I dollar). The whole subject of tick control is reviewed very thoroughly, and this booklet can claim to cover the whole of the subject from the angle of the field veterinary officer. It contains a select reference list of titles dating from 1941. The nine chapters deal with reasons for controlling ticks; control of parasites off the host: control of parasites on the host; timing of ixodicidal applications; ixodicidos; deterioration and depletion of ixodicidal washes and estimation of their concentration; resistance of ticks to ixodicides; toxicity of ixodicides; and a summary. Eight very important pages were left unprinted in the copy received for review; this may also apply to two other pages at the end of the book. It is to be hoped that this has not happened with other copies.

\section{Courses supported by the U.S. National Science Foundation}

Under the title Science Course Improvement Projects the National Science Foundation has issued a booklet listing and describing the courses designed to improve the teaching of science and mathematics as well as engineering supported by the National Science Foundation (NSF 62-38. 1: Courses, Written Materials, Films, Studies supported by the National Science Foundation. Pp. 64. Washington, D.C.: National Science Foundation, 1962). In all, some 132 courses and studies are listed. The projects are arranged in four main groups, concerned first with elementary schools, secondly with secondary schools, thirdly with technical institutes, and fourthly with college and university projects. Under those headings, they are arranged according to disciplines. The information covers courses, written material, films and investigations.

\section{The Simon Population Trust}

THE Simon Population Trust was formed following a bequest of $£ 15,000$ from the late Lord Simon of Wythen. shawe. The objects of the Trust, designedly formulated in broad terms, are: (1) to promote a better understanding of the problems of world population and resources; (2) to encourage such research, education or other actions in any part of the world as may contribute to the adjust. ment of population to resources. The need had long been felt for an objective and independent body, non-partisan and of broad sympathies, which could give encouragement and adequate finaneial support to promising initiatives from any quarter, and which could enable new growing points to develop until a comprehensive and well-balanced provision existed for meeting this important need of modern civilization. By the terms of the Trust, the Trustees are enabled to give support to a wide range of projects. However, as yet they are not in a financial position to subsidize basic researches such as have yielded. the oral methods of contraception which are now on trial. The objectives which the Trustees think are at present worthy of support include the following: birth control in place of abortion; use of midwives; improvement of methods acceptable to Roman Catholics; local mann. facture of contraceptives; reversible sterilization in males; travelling fellowships. Further information is obtainable from the Simon Population Trust, 69 Eccleston Square, London, S.W.1.

\section{Announcements}

Prof. W. M. Falrbank, of Stanford University, has been awarded the 1963 Oliver E. Buckley Solid-State Physics Prize of the American Physical Society, for his work on the properties of helium-3, and especially for his part in the discovery of flux quantization in superconductors.

THe Office of Documentation has issued a booklet surveying the scientific information activities of the National Academy of Sciences-National Research Council (Pub. lication 1031. Pp. vi +49 . Washington, D.C.: National Academy of Sciences-National Research Council, 1962). These are described under the divisional subject heads and, besides listing the various Committees concerned and information services, the booklet lists the various publications available.

THF fifteenth international symposium on "Crop Protection" will be held at the State Agrieultural College. Gent, on May 7. Further information can be obtained from Prof. J. van den Brando, State Agricultural College, Coupure Links, 233, Gent.

THe Plant Phenolics Group is organizing a symposium on "Methods in Polyphenol Chemistry" at the Dyson Perrins Laboratory, Oxford, during April 2-4. Further information can be obtained from the honorary secretary. A. H. Williams, Research Station, Long Ashton, Bristol.

AN international symposium on "Physical Processes in Radiation Biology" will be held at Michigan State University during May 5-8. Further information can be obtained from Mr. Bruce Alderman, Room 24, Kellogg Center, Michigan State University, East Lansing, Michigan.

THE spring meeting of the British Society of Rheoloy will be held at the Colloge of Aeronauties, Cranfielil. during April 17 19. The subject of the meoting will be "Ductility in Metals and its Relation to Fabrication Processes". Non-members of the Society are invited to participate in the meeting. Further information ean be obtained from Mr. R. Pearce, Department of Materials. Cranfield, Bletchley, Bucks.

The British Radio Spectroscopy Group is organizing a conference on "Ions, Masers and Irradiation" at the Physics Department, University of Keele, during April 8-10. The topies covered will include the experimental and theoretical investigations of both bound and free ions: the relation of such investigations to optical, infra-red and microwave masers; the use of microwave spectroscopy to detect effects produced by irradiation at radio, microwave or optical frequencies. Further information and registration forms are available from Dr. D. C. Lainé, Physics Department, University of Keele, Staffs. 